\title{
Osteogenic Differentiation of Human Umbilical Cord Mesenchymal Stromal Cells in Polyglycolic Acid Scaffolds
}

\author{
Limin Wang, Ph.D., ${ }^{1}$ Nathan H. Dormer, B.S., ${ }^{2}$ Lynda F. Bonewald, Ph.D., ${ }^{3}$ and Michael S. Detamore, Ph.D. ${ }^{2}$
}

Although human umbilical cord mesenchymal stromal cells (hUCMSCs) have been shown to differentiate along an osteogenic lineage in monolayer culture, the potential of these cells has seldom before been investigated in three-dimensional scaffolds for bone tissue engineering applications. In this 6-week study, we observed osteogenic differentiation of hUCMSCs on polyglycolic acid (PGA) nonwoven mesh scaffolds, and compared seeding densities for potential use in bone tissue engineering. Cells were seeded into PGA meshes with densities of 5, 25, or $50 \times 10^{6}$ cells $/ \mathrm{mL}$ scaffold and then cultured in osteogenic medium. Cell proliferation, osteogenic differentiation, and matrix formation were evaluated at weeks 0,3 , and 6 . Osteogenic differentiation was observed based on positive alkaline phosphatase activity and an increase of collagen production and calcium incorporation into the extracellular matrix, which increased with higher cell density. During differentiation, runt-related transcription factor (RUNX2), type I collagen $(C I)$, and osteocalcin $(O C N)$ gene expression levels were also increased. In conclusion, exposed to osteogenic signals, hUCMSCs differentiated along an osteogenic lineage as determined by expression of osteogenic markers and matrix formation, and increasing the density of hUCMSCs seeded onto three-dimensional PGA scaffolds led to better osteogenic differentiation.

\section{Introduction}

A UTOLOGOUS BONE GRAFTS are currently the most common clinical treatment of critical-sized bone defects. ${ }^{1}$ However, there remain several drawbacks that limit their application, including limited availability, invasive bone tissue harvesting, and donor-site morbidity. ${ }^{1,2}$ Bone tissue engineering, which aims to restore the biological and mechanical function of diseased and damaged bone, holds the greatest promise for future clinical practice. ${ }^{3,4}$ This approach integrates cells, bioactive molecules, and biocompatible scaffolds for direct implantation to facilitate bone regeneration in vivo or to create a replacement in vitro for implantation. Bone-marrow-derived mesenchymal stem cells (BMSCs) have been extensively investigated as a cell source for bone tissue engineering. ${ }^{5}$ However, the available cell number of BMSCs in bone marrow and their differentiation potential decreases significantly with age. ${ }^{6,7}$ Moreover, the harvesting procedure is painful and invasive, and may lead to complications and morbidity. 8

Recently, human umbilical cord mesenchymal stromal cells (hUCMSCs) have been explored as a promising cell source for tissue engineering and regenerative medicine. ${ }^{9}$ UCMSCs are extracted through enzyme digestion from Wharton's jelly of umbilical cords, ${ }^{10,11}$ which yields
$10-50 \times 10^{3}$ cells per $\mathrm{cm}$ of cord $^{12}$ corresponding to approximately $2-10 \times 10^{5}$ primary cells per cord. hUCMSCs express classic surface markers identified in BMSCs, including CD29, CD44, CD90, CD105, and CD166 $6^{13,14}$ and markers found in embryonic stem cells, including Oct-4, Nanog, and Sox-2 transcription factors. ${ }^{15}$ With exogenous signals such as dexamethasone $\mathrm{e}^{13,16-18}$ or osteoinductive biomaterials such as demineralized bone matrix ${ }^{19}$ hUCMSC s have been shown to differentiate along the osteogenic lineage, confirmed by positive von Kossa staining ${ }^{13,16-18}$ Alizarin red staining, ${ }^{13}$ alkaline phosphatase (ALP) activity, ${ }^{13,16-19}$ osteopontin (OPN) gene upregulation, ${ }^{16,18}$ and bone-related proteins such as $O P N$, osteonectin, osteocalcin $(O C N)$, and bone sialoprotein$2 .^{13}$ Their osteogenic ability accompanied by numerous other advantages over human BMSCs (hBMSCs) indicates that hUCMSCs may be a promising candidate as a stem cell source for bone tissue engineering.

Osteogenic differentiation of hUCMSCs in threedimensional (3D) scaffolds in vitro is scarcely explored in the literature with only three studies ${ }^{20-22}$ using different materials. The studies by Schneider et al. ${ }^{20}$ and Zhang et al. ${ }^{21}$ compared hBMSCs and hUCMSCs using osteoconductive materials such as poly $\varepsilon$-caprolactone/ $\beta$-tricalcium phosphate composites and type I collagen $(C I)$ gels. In a recent study from our group, ${ }^{22}$ signaling strategies for osteogenic

\footnotetext{
${ }^{1}$ Department of Biomedical Engineering, University of Michigan, Ann Arbor, Michigan.

${ }^{2}$ Department of Chemical and Petroleum Engineering, University of Kansas, Lawrence, Kansas.

${ }^{3}$ Department of Oral Biology, University of Missouri-Kansas City, Kansas City, Missouri.
} 
differentiation were investigated using poly(L-lactic acid) (PLLA) scaffolds. These 3D studies are a significant leap forward from differentiation studies in monolayer culture. In a 3D environment, many parameters, such as the biocompatibility of materials, diffusion parameters, and cell seeding methods, are known to affect cell differentiation and proliferation and extracellular matrix (ECM) synthesis. ${ }^{23}$ In the current study, we focused on the effects of initial cell seeding density on hUCMSC differentiation using polyglycolic acid (PGA), a nonosteoinductive material approved for various applications by the FDA. We have recently shown in a chondrogenic application of hUCMSCs that a seeding density above $25 \times 10^{6}$ cells $/ \mathrm{mL}$ was optimal. ${ }^{12}$ In another study, a low cell seeding density resulted in a low seeding efficiency in a poly(lactic-co-glycolic acid) scaffold and delayed in vivo mineralization. ${ }^{24}$ Further, in collagen scaffolds, high seeding densities of hBMSCs augmented scaffold contraction ${ }^{25}$ and a specific range of seeding densities $\left(3-30 \times 10^{6}\right.$ cells $\left./ \mathrm{mL}\right)$ enhanced osteoblastic differentiation of an osteosarcoma cell line. ${ }^{23}$ The present study thus aimed to investigate how the seeding density of hUCMSCs affected their osteogenic differentiation and subsequent matrix production in a 3D environment. The hypothesis for this study was that a higher seeding density would result in enhanced osteogenic differentiation with an increase in bone-related matrix synthesis.

\section{Materials and Methods}

\section{Cell harvest}

Human umbilical cord collection and cell harvests were approved by the University of Kansas Human Subject Committee (KU-Lawrence IRB approval no. 15402 and KU Medical Center IRB approval no. 10951). All cords were collected from the University of Kansas Medical Center and processed within $24 \mathrm{~h}$. Cells obtained from one cord (female, $\sim 26 \mathrm{~cm}$ in length) was used to examine the effects of different cell densities on osteogenic differentiation, and then cells from four different umbilical cords (two male and two female, $\sim 20 \mathrm{~cm}$ each) were pooled to evaluate osteogenic differentiation at a gene expression level using the cell density that resulted in the largest amount of bone-related matrix among the three tested densities. Our preliminary studies revealed that cells harvested from different cords ( $>50$ cords) consistently shared a similar expression profile of surface antigens. They were positive for typical MSC markers such as CD73, CD90, and CD105, and were negative for hematopoietic markers such as CD34 and CD45. After cord collection, cords were first cut into $3-5 \mathrm{~cm}$ pieces, and then vessels were removed from each cord segment. Cord segments were minced and incubated in $0.75 \mathrm{mg} / \mathrm{mL}$ type II collagenase (298 U/mg; Worthington Biochemical, Lakewood, NJ) at $37^{\circ} \mathrm{C}$. After a 5-h incubation, a homogenous gelatinous solution was obtained and diluted (1:8) in sterile phosphate-buffered saline. The solution was centrifuged, the supernatant was discarded, and cells were resuspended in a complete culture medium consisting of low-glucose Dulbecco's modified Eagle's medium (Invitrogen, Carlsbad, CA), 10\% MSC-qualified fetal bovine serum (StemCell Technologies, Vancouver, Canada), and $1 \%$ penicillin/ streptomycin (Invitrogen). Cells were plated in cell culture flasks at 8000 cells $/ \mathrm{cm}^{2}$ (P0 cells) and fed every 2 to 3 days. When cells had reached $80 \%-90 \%$ confluency, they were detached by $1 \times$ trypsin (Invitrogen) and resuspended at a density of $1 \times 10^{6}$ cells per $\mathrm{mL}$ freezing medium, composed of $90 \%$ fetal bovine serum and 10\% dimethyl sulfoxide (Fisher Scientific, Pittsburgh, PA). The cell suspension was transferred into cryotubes (Nalgene Labware, Rochester, NY), which were stored in Mr. Frosty freezing containers (Nalgene Labware) at $-80^{\circ} \mathrm{C}$ overnight, and transferred to a liquid nitrogen cryogenic storage system at $-196^{\circ} \mathrm{C}$ for future use.

\section{Cell culture and seeding}

Cells were thawed and expanded to P4 in the complete medium. Nonwoven PGA meshes $(50 \mathrm{mg} / \mathrm{cc} ;>95 \%$ porosity; Synthecon, Houston, TX) were punched into 96 cylinder-shape scaffolds with a $5 \mathrm{~mm}$ diameter and $2 \mathrm{~mm}$ thickness, and then sterilized with ethylene oxide. After sterilization, the scaffolds were aired under a fume hood for 1 day, and then wetted with sterile filtered ethanol and two washes of sterile phosphate-buffered saline. The scaffolds were then soaked in the complete medium in 24-well plates for 1 day and then removed for cell seeding. P4 hUCMSCs were seeded at 5 (low), 25 (medium), and 50 (high) $\times 10^{6}$ cells per $\mathrm{mL}$ of scaffold. In brief, $400 \mu \mathrm{L}$ of the medium was used to resuspend $19.0 \times 10^{3}, 982 \times 10^{3}$, or $1.96 \times 10^{6}$ cells, resulting in cell densities of 5,25 , or $50 \mathrm{M}$ cells $/ \mathrm{mL}$ in the scaffolds. The cell solution was then transferred to well plates and pipetted 10 times through the scaffolds. Well plates were then set on orbital shakers at $150 \mathrm{rpm}$ for $24 \mathrm{~h}$. In the medium- and highdensity groups, this small amount of medium containing a large amount of cells yielded a highly concentrated cell solution, which caused the formation of several cell clusters in the medium, some of which attached lightly to the peripheral area of PGA scaffolds and detached from the edge when the medium was changed. After the first $8 \mathrm{~h}, 400 \mu \mathrm{L}$ of the medium was added. After the $24 \mathrm{~h}$ orbital shaking period, cells were allowed to attach statically in the culture medium for another day. Finally, the complete medium was replaced by $2 \mathrm{~mL}$ of the osteogenic medium, which was the complete medium plus $100 \mathrm{nM}$ dexamethasone (Sigma, St. Louis, MO), $10 \mathrm{mM} \beta$-glycerophosphate (Sigma), $50 \mu \mathrm{g} / \mathrm{mL}$ ascorbic acid 2-phosphate (Sigma), and $10 \mathrm{nM} \mathrm{1} 1 \alpha, 25$-dihydroxyvitamin D3 (Biomol International, Plymouth Meeting, PA). This time point was recorded as week 0 . About $1.5 \mathrm{~mL}$ of the medium was changed every other day for 6 weeks. At weeks 3 and 6, separate groups of constructs were analyzed for hydroxyproline (HYP) content, ALP, calcium content, and histological analysis. Hydroxyproline content was also measured at week 0 to demonstrate minimal initial differences in matrix content between groups.

\section{DNA and HYP content}

Constructs $(n=4)$ were homogenized in $1.2 \mathrm{~mL}$ papain solution $(120 \mu \mathrm{g} / \mathrm{mL})$ using a tissue homogenizer (Omni International, Marietta, GA), and incubated in this solution at $60^{\circ} \mathrm{C}$ overnight, before storing at $-20^{\circ} \mathrm{C}$ for future biochemical assays. The DNA content was determined by using a PicoGreen kit (Invitrogen) according to the manufacturer's protocol. A conversion factor of $8.5 \mathrm{pg}$ DNA/cell was determined in preliminary studies and used to convert DNA content to cell number. HYP content was determined by using a HYP assay as described previously. ${ }^{26}$ Briefly, each sample was hydrolyzed with sodium hydroxide, neutralized 
with hydrochloric acid, and then titrated to a $\mathrm{pH}$ range from 6.5 to 7.0. This solution was combined with chloramine-T buffer and $p$-dimethylaminobenzaldehyde in perchloric acid and read spectrophotometrically at $550 \mathrm{~nm}$. A conversion factor of 11.5 can be used to convert HYP mass to collagen mass, based on our preliminary studies.

\section{ALP activity}

Constructs $(n=4)$ were homogenized in $500 \mu \mathrm{L}$ of $0.2 \%$ Triton X-100 (Sigma) and lysed twice using freeze-thaw cycles. The lysate was used to determine ALP following a previously described method. ${ }^{27}$ In brief, $20 \mu \mathrm{L}$ of lysate was combined with $80 \mu \mathrm{L}$ of $1.5 \mathrm{M}$ 2-amino-2-methyl-1-propanol (Sigma) buffer ( $\mathrm{pH}$ 10.3) containing $5 \mathrm{mM}$-nitrophenol phosphate substrate (Sigma). For the standard curve, serial dilutions of $0-20 \mathrm{nM}$ p-nitrophenol (Sigma) were made in triton solution. The reaction was stopped by adding $100 \mu \mathrm{L}$ of $0.5 \mathrm{M} \mathrm{NaOH}$. The solution was then read spectrophotometrically at $405 \mathrm{~nm}$. ALP activity was normalized to total DNA content.

\section{Calcium content}

Constructs $(n=4)$ were homogenized, suspended in $1 \mathrm{~N}$ acetic acid overnight, and stored at $-20^{\circ} \mathrm{C}$ for future assays. An ortho-cresolphthalein complexone (OCPC) method was used to measure calcium content as described previously. ${ }^{28}$ The OCPC solution consisted of $1 \mathrm{mg} / \mathrm{mL}$ OCPC in a buffer including $0.0063 \mathrm{~N} \mathrm{KOH}$ and $0.0031 \mathrm{~N}$ acetic acid. The working solution contained $0.05 \mathrm{mg} / \mathrm{mL}$ OCPC solution, $0.74 \mathrm{M}$ ethanolamine/boric acid buffer $(\mathrm{pH} 11)$, and $2 \%$ 8-hydroxyquinoline ( $5 \mathrm{~g}$ in $100 \mathrm{~mL}$ of $95 \%$ ethanol). About $0-100 \mathrm{mg} / \mathrm{mL} \mathrm{CaCl}_{2}$ solution (Sigma) was used as the standard. A solution including $50 \mu \mathrm{L}$ of culture sample and $250 \mu \mathrm{L}$ of working solution was incubated for $10 \mathrm{~min}$ at room temperature and then read spectrophotometrically at $575 \mathrm{~nm}$.

\section{Histology}

Samples were embedded in an OCT compound (TissueTek, Torrance, CA) and frozen sections $(10 \mu \mathrm{m})(n=2)$ were cut using a cryostat (Micron HM-550 OMP, Vista, CA). For the von Kossa stain, sections were incubated with $1 \%$ silver nitrate solution in a clear plastic Coplin jar, placed under ultraviolet light for $20 \mathrm{~min}$, and then rinsed in ultrapure water. In addition, hematoxylin stains were performed with hematoxylin-QS from Vector Laboratories (Burlingame, CA). Finally, all slides were dehydrated with graded alcohol $(95 \%$ and $100 \%$ twice each) and mounted.

\section{Osteogenic gene expression analysis}

Gene expression was monitored during the crucial early period of osteogenic differentiation at 1 week time points to evaluate cell phenotype during this period. Expression of genes of osteogenic differentiation was determined using a seeding density of $50 \times 10^{6}$ cells per mL. A total of 32 scaffolds were seeded as described above, and after the seeding period, half of them continued in the complete medium and the other half were cultured in the aforementioned osteogenic medium. Four scaffolds from each group were harvested at time points of $0,1,2$, and 3 weeks. Total RNA extraction was conducted using Trizol reagent (Invitrogen) following the manufacturer's instructions $(n=4)$. The reverse transcription from mRNA to cDNA was achieved using a High-Capacity cDNA Archive kit (Applied Biosystems, Foster City, CA) following the supplier's procedure. A real-time polymerase chain reaction was used for gene expression of $C I$, runtrelated transcription factor 2 (RUNX2), OCN, and OPN using

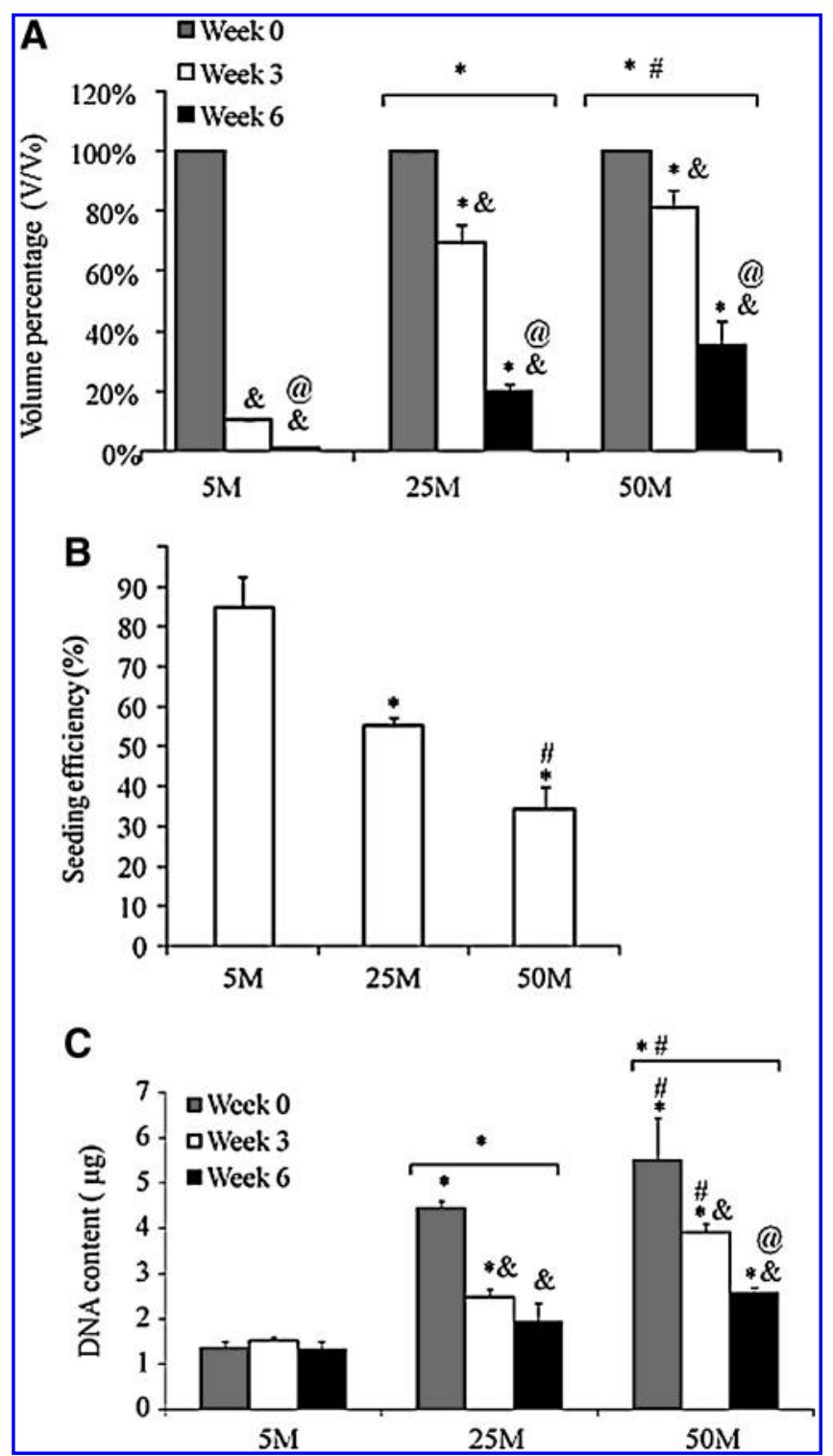

FIG. 1. Construct volume (A) $(n=3)$, seeding efficiency $(\mathbf{B})$ $(n=4)$, and DNA content per construct $(\mathbf{C})(n=4)$. Decreases in DNA content and construct volume were generally observed over time. *Statistically significant difference $(p<0.05)$ from the low-density group $(5 \mathrm{M})$. "Statistically significant difference between the medium-density (25 M) and high-density $(50 \mathrm{M})$ groups. ${ }^{\&}$ Statistically significant difference from week 0 . ${ }^{\circledR}$ Statistically significant difference between weeks 3 and 6 . The symbols in top brackets represent significant differences between the different density groups throughout the whole culture period. $V$, the scaffold volume; $V_{0}$, the scaffold volume at week 0 . Error bars represent standard deviations. A conversion factor of $8.5 \mathrm{pg}$ DNA/cell can be used to convert DNA content to cell number. 
Table 1. Average Mean Values of Different Time Points at a Specific Density (Mean And Standard Deviation)

\begin{tabular}{lccccccc}
\hline Group & $\begin{array}{c}\text { Final } \\
\text { volume }(\%)\end{array}$ & $\begin{array}{c}\text { DNA } \\
(\mu g)\end{array}$ & $\begin{array}{c}\text { HYP per } \\
\text { construct }(\mu g)\end{array}$ & $\begin{array}{c}\text { HYP per } \\
\text { unit DNA }(\mu \mathrm{g} / \mu \mathrm{g})\end{array}$ & $\begin{array}{c}\text { Calcium per } \\
\text { construct }(\mu \mathrm{g})\end{array}$ & $\begin{array}{c}\text { Calcium per } \\
\text { unit DNA }(\mu \mathrm{\mu g} / \mu \mathrm{g})\end{array}$ & $\begin{array}{c}\text { ALP activity } \\
(\mathrm{nmol} / \mathrm{h} / \mathrm{DNA})\end{array}$ \\
\hline $5 \mathrm{M}$ & $37(54)$ & $1.41(0.15)$ & $0.087(0.074)$ & $0.062(0.047)$ & $3.6(2.4)$ & $2.3(1.7)$ & $4.36(0.97)$ \\
$25 \mathrm{M}$ & $63(40)$ & $3.0(1.2)$ & $0.23(0.13)$ & $0.098(0.071)$ & $168(100)$ & $82(56)$ & $5.8(1.6)$ \\
$50 \mathrm{M}$ & $73(33)$ & $4.0(1.4)$ & $0.38(0.19)$ & $0.12(0.08)$ & $297(160)$ & $105(72)$ & $6.76(0.99)$ \\
\hline
\end{tabular}

$5 \mathrm{M}, 25 \mathrm{M}$, and $50 \mathrm{M}$ refer to the low-, medium-, and high-density groups, respectively.

ALP, alkaline phosphatase; HYP, hydroxyproline.

TaqMan gene expression assay kits (Applied Biosystems) in an Applied Biosystems 7500 Fast System. The kits were Hs00164004_m1 for CI, Hs00231692_m1for RUNX2, Hs01587813_g1 for OCN, Hs00167093_m1 for OPN, and Hs99999905_m1 for glyceraldehyde 3-phosphate dehydrogenase. A $2^{-\Delta \Delta C t}$ method was used to evaluate the relative level for each target gene. ${ }^{29}$

\section{Statistical analysis}

All data were expressed as means \pm one standard deviation, and analyzed by analysis of variance followed by Tukey's Honestly Significant Difference post hoc tests. Two-way analysis of variances with interaction was used to determine whether there were differences among either time-points or seeding densities. A statistical threshold of $p<0.05$ was used to indicate whether there were statistical significances among different groups.

\section{Results}

\section{Scaffold morphology and DNA content}

The shape of the scaffolds changed from cylindrical at week 0 to spherical at weeks 3 and 6 . Scaffold volume decreased in all groups over the course of the 6-week period, with higher-density groups being larger than lower-density groups (Fig. 1A and Table 1). There were significant differences among the seeding efficiencies (defined as the ratio of the DNA content of attached cells to the DNA content of seeded cells), with $84.7 \pm 8.1 \%$ at the low density, $55.1 \pm 2.1 \%$ at the medium density, and $34.2 \pm 5.8 \%$ at the high density $(p<0.05)$ (Fig. 1B). On the whole, the DNA content decreased with time $(p<0.05)$ throughout the culture period (Fig. 1C). The higher-density groups had more DNA than the lower-density groups $(5<25<50 \mathrm{M})(p<0.05)$ (Fig. $1 \mathrm{C}$ and Table 1). The low-density group maintained the DNA content over the 6-week culture time, the medium-density group deceased in DNA content only from weeks 0 to $3(p<0.05)$, and the high-density group decreased in DNA content at both weeks 3 and $6(p<0.05)$. At week 6 , the high-density group $(4.0 \pm 1.4 \mu \mathrm{g})$ had more DNA than the low-density group $(1.41 \pm 0.15 \mu \mathrm{g})(p<0.05)$ and had no significant difference from the medium-density group $(3.0 \pm 1.2 \mu \mathrm{g})$. With the drastic drop in the volume of the low-density group, the cellularity (DNA per volume) in the medium and highdensity groups was significantly lower than that in the lowdensity group at week $6(p<0.05)$. There was no significant difference in cellularity between the medium and highdensity groups.

\section{HYP content}

The higher-density group maintained a higher HYP content per construct during the 6-week culture period $(5<25<50 \mathrm{M})(p<0.05)$ (Fig. 2A and Table 1$)$. The highdensity group had 2.3 and 17 times more HYP per construct

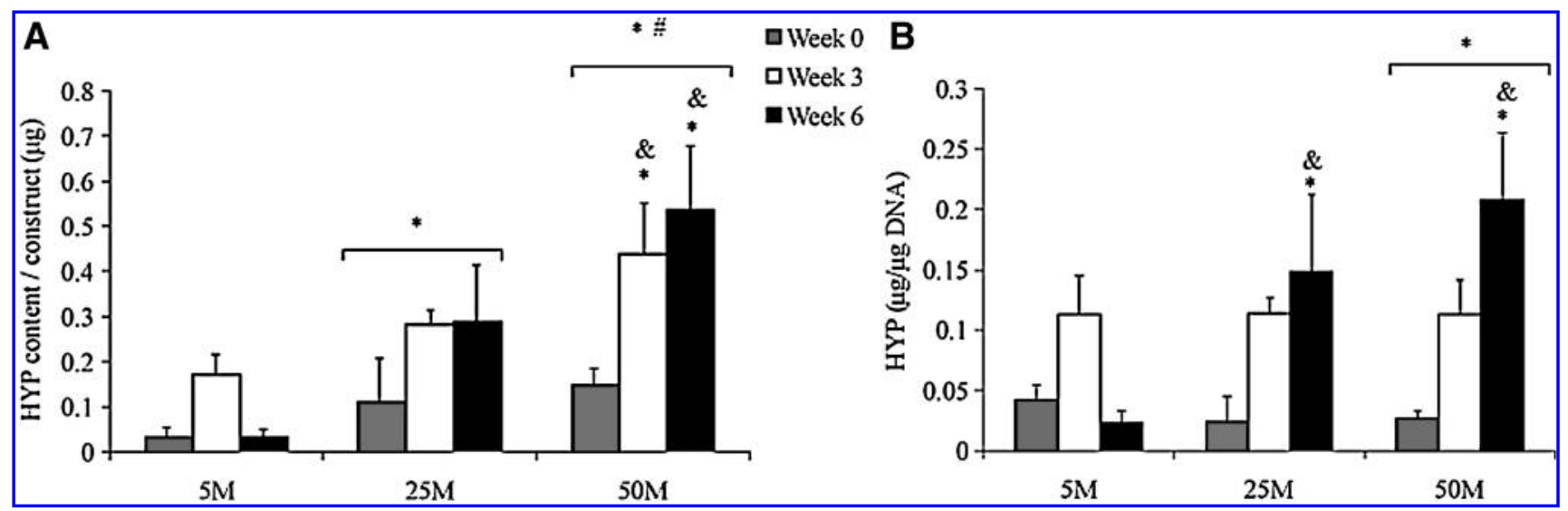

FIG. 2. Hydroxyproline (HYP) content per construct $(\mathbf{A})$ and per unit DNA $(\mathbf{B})(n=4)$. Higher-density groups produced more collagen per construct and per unit DNA. *Statistically significant difference $(p<0.05)$ from the low-density group $(25 \mathrm{M}) .{ }^{\&}$ Statistically significant difference from week $0 .{ }^{\#}$ Statistically significant difference between the medium-density $(25 \mathrm{M})$ and high-density $(50 \mathrm{M})$ groups. The symbols in top brackets represent significant differences between the different density groups throughout the whole culture period. Error bars represent standard deviations. 


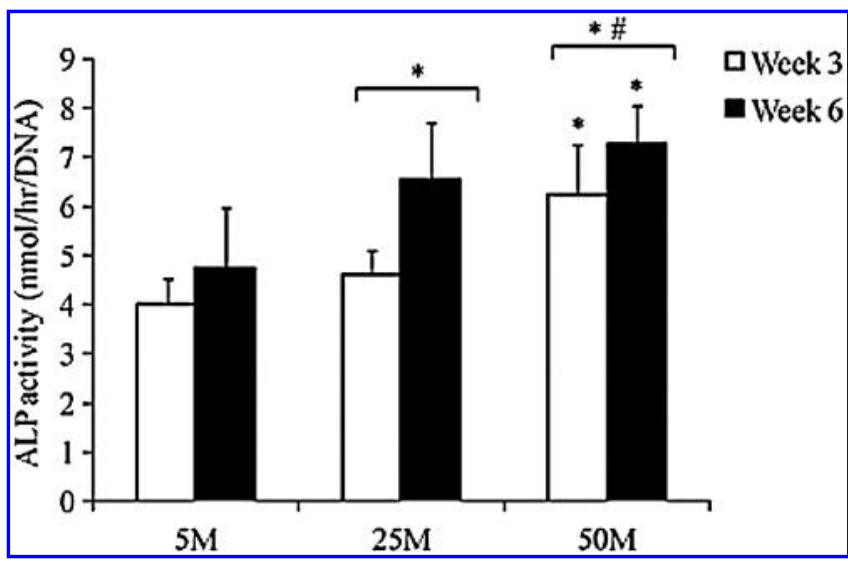

FIG. 3. Alkaline phosphatase (ALP) activity at weeks 3 and $6(n=4)$. Higher-density groups had higher ALP activity per unit DNA. *Statistically significant difference $(p<0.05)$ from the low-density group (5M). "Statistically significant difference between the medium-density $(25 \mathrm{M})$ and high-density $(50 \mathrm{M})$ groups. The symbols in top brackets represent significant differences between the different density groups throughout the whole culture period. Error bars represent standard deviations.

than the low-density group at weeks 3 and $6(p<0.05)$, respectively, whereas there was no significant difference between the low-density and medium-density groups at weeks 3 and 6. In the high-density group, the HYP content per construct was 3.0 and 3.6 times higher at weeks 3 and 6 than at week $0(p<0.05)$, respectively. With regard to HYP content per unit DNA, the high-density group had significantly higher content than the low-density group $(p<0.05)$, whereas no significant difference was detected between the medium and high-density groups (Fig. 2B). At week 6, the medium and high-density groups had 6.4 and 9.0 times more HYP per unit DNA, respectively, than the low-density group $(p<0.05)$. Both the medium and high-density groups had more HYP per unit DNA at week 6 than at week $0(p<0.05)$, whereas there were no significant differences between weeks 3 and 6 . In the low-density group, the highest HYP content per construct and per unit DNA was observed at week 3, although there were no significant differences among weeks 0,3 , and 6 .

\section{ALP activity}

The higher-density groups had a higher level of ALP activity (measured on a per DNA basis) than the lower-density groups $(5<25<50 \mathrm{M})(p<0.05)$ (Fig. 3 and Table 1). At week 6 , the medium $(6.5 \pm 1.2 \mathrm{nmol} / \mathrm{h} / \mathrm{DNA})$ and highdensity groups $(7.28 \pm 0.76 \mathrm{nmol} / \mathrm{h} / \mathrm{DNA})$ had $38.1 \%$ $(p>0.05)$ and $53.9 \%(p<0.05)$ higher ALP activity than the low-density group $(4.7 \pm 1.2 \mathrm{nmol} / \mathrm{h} / \mathrm{DNA})$, respectively. From weeks 3 to 6 , ALP activities increased for all three groups, although these differences were not statistically significant.

\section{Calcium content and histology}

In general, the higher-density constructs had higher calcium content both per construct (Fig. 4A and Table 1) and per unit DNA (Fig. 4B) than at a lower density $(p<0.05)$ $(5<25<50 \mathrm{M})$. Only a small amount of calcium (less than $4 \mu \mathrm{g}$ per construct and $3 \mu \mathrm{g} / \mu \mathrm{g}$ DNA) was detected in the low-density group. Both the medium and high-density groups at week 6 had 2.9 times more calcium per construct than at week $3(p<0.05)$. Calcium contents per unit DNA in the medium- and high-density groups at week 6 were 3.7 and 4.4 times higher than at week $3(p<0.05)$, respectively. The low-density group maintained its calcium content at a low level between weeks 3 and 6, both per construct and per unit DNA. von Kossa staining suggested that mineralization increased with time and with seeding density (Fig. 5), which was consistent with calcium quantification. Hematoxylin staining demonstrated that the cellularity (i.e., cell density, the cells per area) in all groups increased from weeks 3 to 6 , and that the low-density group had a higher cellularity than the medium- and high-density groups at week 6 (Fig. 6).

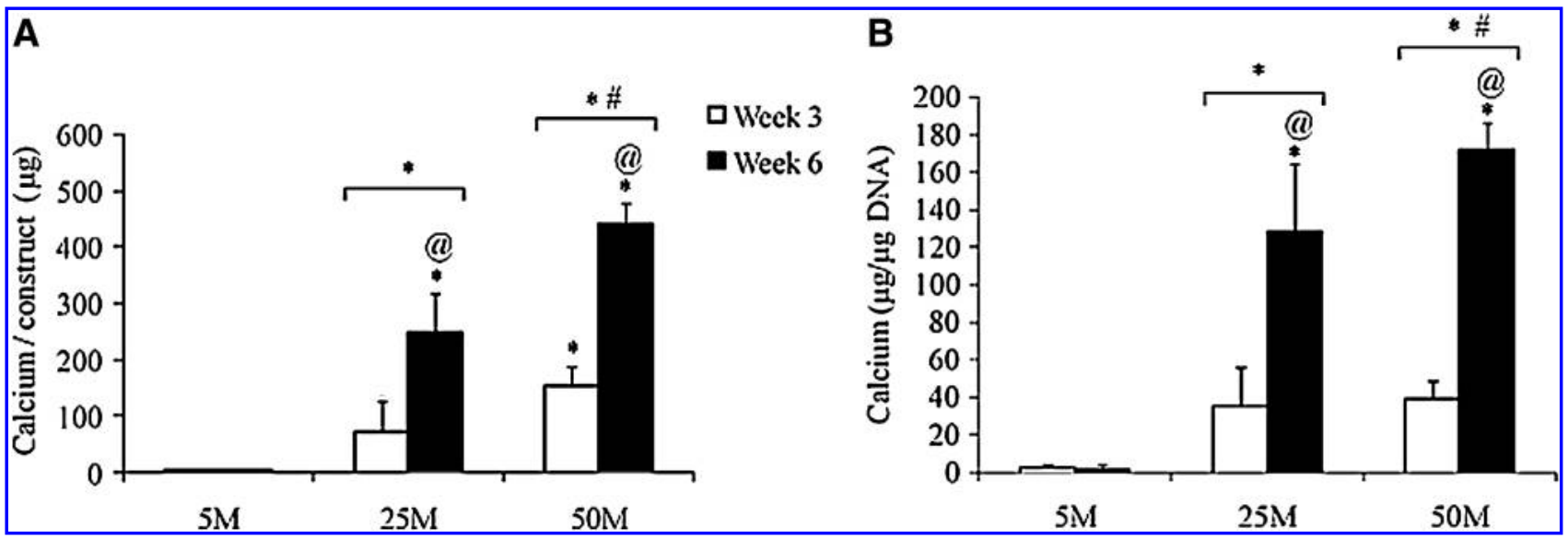

FIG. 4. Calcium content per construct (A) and per unit DNA $(B)$ at weeks 3 and $6(n=4)$. Higher-density groups had more calcium per construct and per unit DNA. *Statistically significant difference $(p<0.05)$ from the low-density group $(5 \mathrm{M})$. ${ }^{\#}$ Statistically significant difference between the medium-density $(25 \mathrm{M})$ and high-density (50 M) groups. ${ }^{\circledR}$ Statistically significant difference between weeks 3 and 6 . The symbols in top brackets represent significant differences between the different density groups throughout the whole culture period. Error bars represent standard deviations. 
FIG. 5. von Kossa staining at 3 and 6 weeks $(n=2)$. The mineralization increased with time and seeding density. The photos were taken at the central area of the scaffolds. The scale bar is $500 \mu \mathrm{m} .5 \mathrm{M}, 25 \mathrm{M}$, and $50 \mathrm{M}$ means the low-, medium-, and high-density groups, respectively. Color images available online at www .liebertonline.com/ten.

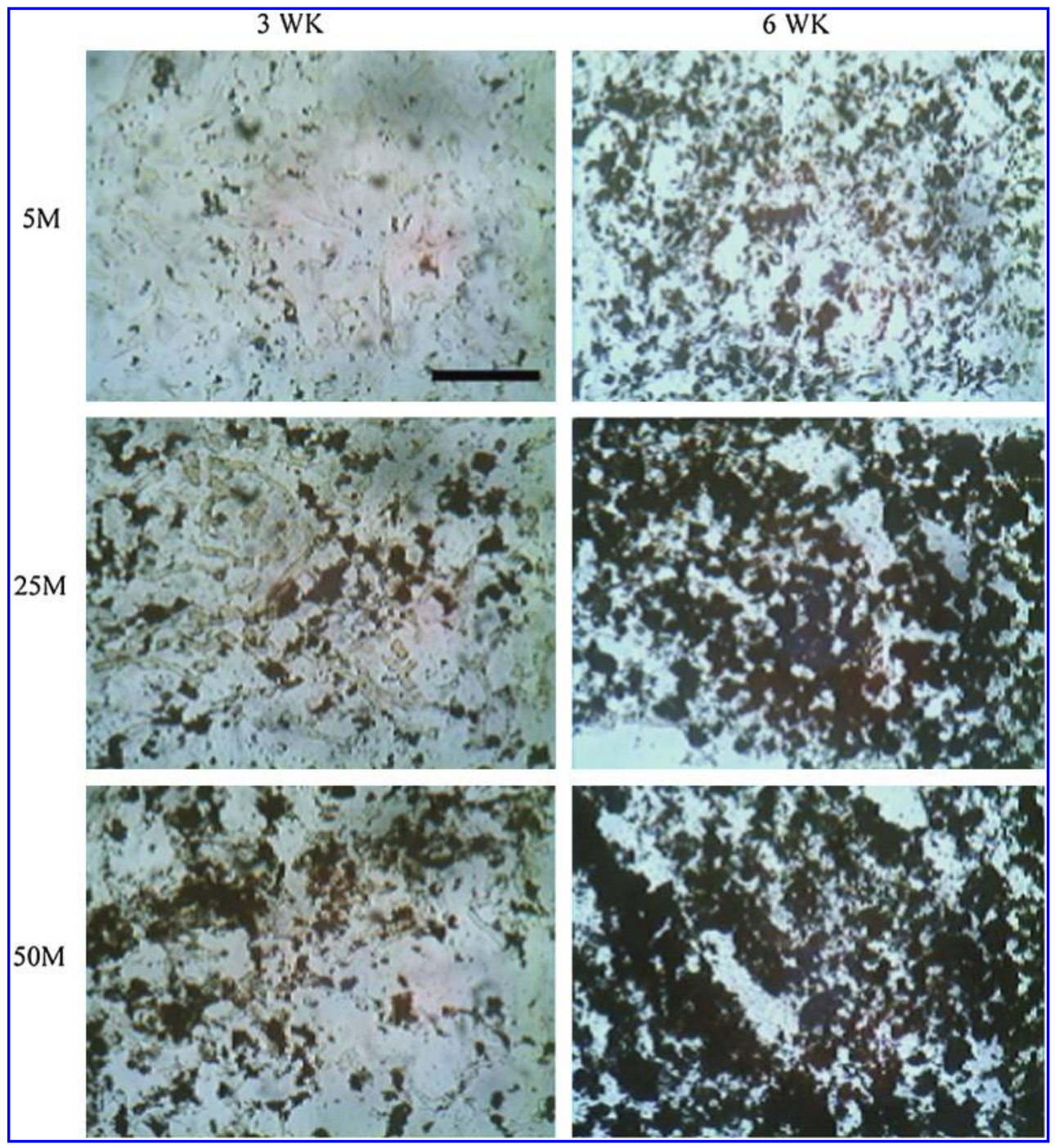

\section{Osteogenic gene expression}

Compared to week 0 , all genes in both osteogenic and control groups, except $O P N$, were upregulated during at least one time point, whereas OPN gene expression decreased after 3 weeks $(p<0.05)$ (Fig. 7). Compared to the control groups, RUNX2 gene expression in the osteogenic groups had a higher level over 3 weeks, and OCN gene expression had a higher level at week 2 but had a lower level at week $3(p<0.05)$. No significant difference in $C I$ and OPN gene expression was observed between the osteogenic and control groups throughout the culture period. Specifically, CI gene expression in both osteogenic and control groups increased during the first 2 weeks by up to 11 times and then decreased by a factor of 3.1 in the osteogenic groups and 6.2 in the control groups from weeks 2 to $3(p<0.05)$. Despite this drop in the osteogenic groups, $C I$ gene expression at week 3 was still 3.8 times higher than at week $0(p<0.05)$. There was no significant difference in $C I$ gene expression between the osteogenic and control groups. RUNX2 gene expression in the osteogenic groups continued to increase in the first 2 weeks $(p<0.05)$ and was then maintained at a same level from week 2 to 3 , with an expression level 7.4 times higher than at week $0(p<0.05)$, whereas the increase of RUNX2 gene expression in the control groups happened mainly in the last 2 weeks ending with 5.1 times higher than at week $0(p<0.05)$. Despite the increase of RUNX2 gene expression in both osteogenic and control groups, the osteogenic groups had a higher expression level than the control groups at each time point except week $0(p<0.05)$. Regarding OCN gene expression, in the osteogenic groups, there was no significant change in the first week, although there was an increase at week 2 by a factor of $2.8(p<0.05)$, and finally a drop at week 3 to a level not significantly different from week 0 . OCN gene expression in the control groups increased only at week 3 to a level 2.7 times higher than at week $0(p<0.05)$. In the comparison between the osteogenic and control groups, the osteogenic groups had an OCN gene expression level 2.3 times higher than the control groups at week $2(p<0.05)$, whereas the control groups had an OCN gene expression level 3.2 times higher than the osteogenic groups at week $3(p<0.05)$. OPN gene expression in both osteogenic and control groups decreased mainly in the first week, dropping $76 \%$ in the osteogenic groups and $90 \%$ in the osteogenic groups $(p<0.05)$, and remained at that lower level for the following 2 weeks. There was no signifi- 


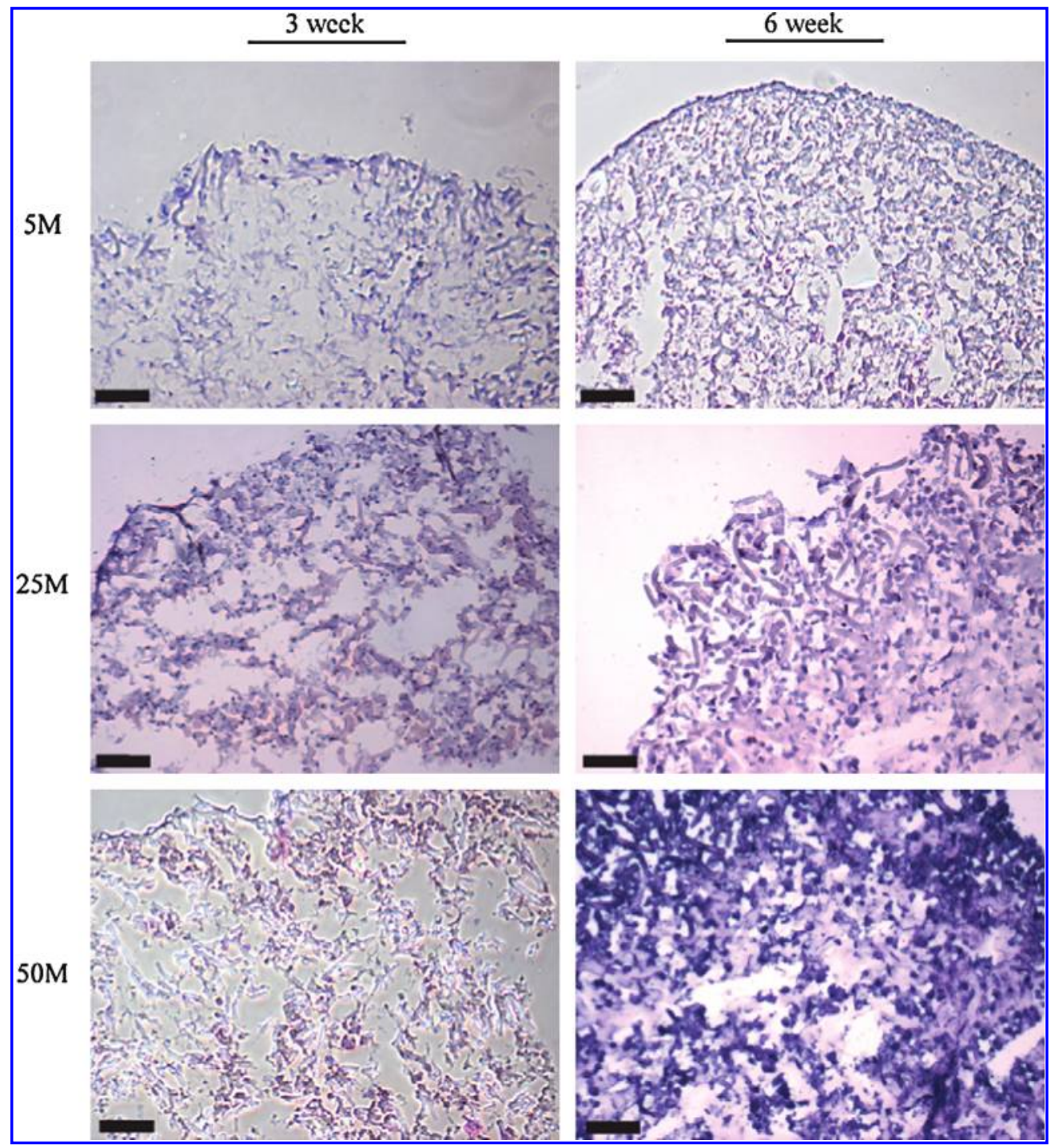

FIG. 6. Hematoxylin staining. The cellularity (i.e., the number of cells per unit area) increased with time. The low-density group had a higher cellularity than the mediumand high-density groups at week 6 . The scale bar is $40 \mu \mathrm{m} .5 \mathrm{M}, 25 \mathrm{M}$, and $50 \mathrm{M}$ refer to the low-, medium-, and high-density groups, respectively. Color images available online at www .liebertonline.com/ten.

cant difference in OPN gene expression between the osteogenic and control groups throughout the culture period.

\section{Discussion}

In this decade, there has been an increasing interest in new cell sources for tissue engineering and regenerative medicine. MSCs with multilineage potential have been identified in various tissues, including bone marrow, ${ }^{30}$ adipose tissue, ${ }^{31}$ blood, ${ }^{32,33}$ synovial fluid, ${ }^{34}$ dermis, ${ }^{35}$ muscle, $^{36}$ dental pulp, ${ }^{37}$ and umbilical cord stroma. ${ }^{14}$ In the present study, we demonstrated that hUCMSCs harvested from umbilical cord stroma were capable of osteogenic differentiation in vitro in a 3D biomaterial-based environment, based on evidence of early markers of osteoblast differentiation. Specifically, biochemical assays and histological staining revealed positive ALP activity with hUCMSCs in the osteogenic medium, and the deposition calcium and phosphate groups throughout the constructs. We also showed that a higher seeding density promoted osteogenic differentiation and increased matrix production by hUCMSCs in PGA scaffolds. These results validated our hypothesis that a higher hUCMSC density results in better osteogenic differentiation and more matrix biosynthesis than lower densities. Although only one donor cord was used in the density study to reduce the number of human subjects required, the results are consistent with a previous study ${ }^{22}$ and our preliminary studies in terms of calcium per DNA (50-300 $\mu \mathrm{g} / \mu \mathrm{g})$. In previous chondrogenic studies using hUCMSCs from different cords, we also observed similar results in terms of glycosaminoglycan and HYP content and immunohistochemical staining with collagen I, collagen II, and aggrecan. Thus, donor variability has not been an issue in our experience to this point, and we expect our results are indicative of results with hUCMSCs in general. However, we do recognize the value of pooling hUCMSCs from different donors for future in vitro studies, and also pooled cells from four different cords for the gene expression profiles in the current study.

hUCMSCs are a promising cell source for tissue engineering for numerous compelling reasons. ${ }^{10}$ First, hUCMSCs are developmentally primitive cells that have been shown to differentiate along mesenchymal lineages and cross into the ectodermal germ layer with neural differentiation. ${ }^{13,14,16-18,38-45}$ Second, umbilical cords are in abundant 


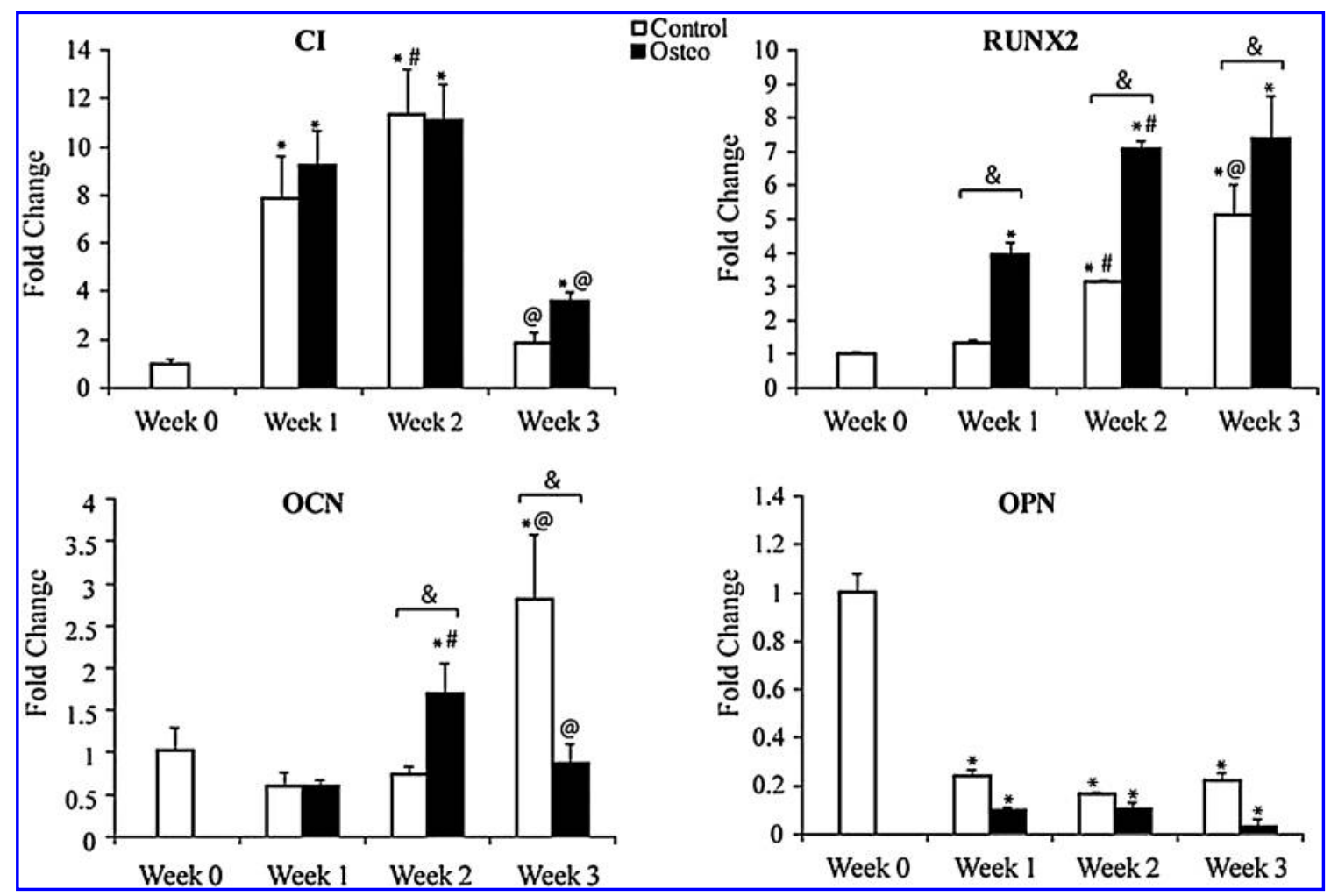

FIG. 7. Gene expression analysis during osteogenic differentiation $(n=4)$. All genes in both osteogenic (Osteo) and control groups, except $O P N$, were upregulated during at least one time point compared to week 0 , whereas OPN gene expression decreased after 3 weeks. Compared to the control groups, RUNX2 gene expression in the osteogenic groups had a higher level at each time point, and OCN gene expression had a higher level at week 2 but had a lower level at week 3 . No significant difference in $C I$ and OPN gene expression was observed between the osteogenic and control groups. * Statistically significant difference from week 0 . \#Statistically significant difference between weeks 1 and 2 . ${ }^{\circledR}$ Statistically significant difference between weeks 2 and 3. ${ }^{\&}$ Statistically significant difference between the osteogenic and control groups. CI, type I collagen; OCN, osteocalcin; RUNX2, runt-related transcription factor; OPN, osteopontin.

supply and easily accessible, as there is a virtually endless supply of umbilical cords with 4.1 million births in the United States alone in $2005 .^{46}$ Therefore, these cells have practical advantages over both embryonic stem cells and BMSCs. Third, after cell harvesting, hUCMSCs can be expanded 300-fold for over seven passages without the loss of differentiation potential. ${ }^{13}$ The rapid proliferation rate and availability make it possible to obtain a large amount of cells in a short time (orders of magnitude faster than BMSCs). Fourth, there is no donor-site morbidity and there are no sensitive political issues. hUCMSCs can be frozen at birth (as is commonly done with cord blood) as an autologous cell source. Fifth, as an allogeneic source, several studies have supported their immunocompatibility and even immunosuppressive nature of hUCMSCs. ${ }^{14,41,47,48}$ In fact, Weiss and colleagues ${ }^{14,47,49}$ have demonstrated that UCMSCs survived in the extreme case of xenotransplantation, with no evidence of a host immune response for up to 12 weeks. All of these characteristics make hUCMSCs a suitable, attractive, and potentially preferred cell source for tissue engineering. However, the application of hUCMSCs for tissue engineering is virtually unexplored with only a few studies conducted in the past 3 years, some of which have focused on cardiovascular tissue engineering. ${ }^{50-55}$ Our group has focused on the application of hUCMSCs in cartilage ${ }^{12,38,56,57}$ and now bone tissue engineering (this study).

In this study, different seeding densities led to noticeable differences in seeding efficiency. The lower seeding efficiency at higher density was explained by cell aggregation (the formation of cell clusters) in the medium during the initial seeding period. We have improved the seeding efficiency at high densities by pipetting the cell solution in 2-h intervals for $8 \mathrm{~h}$ to prevent the formation of cell clusters for the future studies. Nonetheless, the higher-density groups had more DNA (thus, more cells) after seeding and maintained the higher DNA contents compared to the lower-density groups over the duration of the culture period. The DNA content decreased over time in the medium and high-density groups. There are several possible explanations for this reduction. First, dexamethasone is known to inhibit cell proliferation. Second, the degradation rate of PGA scaffolds was faster than the rate of matrix production, leading to a decrease in volume over time (the contraction of scaffolds). During the contraction, many cells and PGA debris fell into the medium, which was observed under a microscope. This cell loss due to degradation has been observed in other studies with PGA scaffolds in cartilage tissue engineering ${ }^{12,56}$ and with collagen scaffolds in bone tissue engineering. ${ }^{58}$ The DNA content 
in the low-density group was maintained over the culture period, although the scaffold experienced the most aggressive degradation in this group. We might speculate that the scaffold completely collapsed on itself with this group due to the insufficient cell number, essentially resembling a cell pellet that was able to rebound in cell number but not in construct volume in the allotted time frame. The high density of cells per area from the histology data (Fig. 6) is consistent with the higher ratio of DNA content to scaffold volume for this group. A scaffold with a slower degradation rate (e.g., PLLA or poly[lactic-co-glycolic acid]) might help to retain cells in scaffolds over a 6-week culture period, although a preculture period of less than 6 weeks may be more desirable for in vivo implantation. In fact, we have observed in our unpublished work that PLLA with hUCMSCs results in over $80 \%$ seeding efficiency and maintains its original shape in over 6 weeks of culture with hUCMSCs.

The formation of ECM and the osteogenic differentiation of hUCMSCs were clearly influenced by the initial seeding densities. The constructs in the higher-density groups had noticeably more HYP and calcium than the lower-density groups. More importantly, the higher-density groups also had more HYP and calcium content per unit DNA than the lower-density groups, indicating that the high density promoted ECM production for the average cell. Cell death (both necrosis and apoptosis) may exist during the course of osteogenic differentiation, which would result in the collection of calcium mineral intracellularly and pericellularly, which would then contribute to the measured calcium content. However, this study achieved similar values of calcium per unit DNA (100-200 $\mu \mathrm{g} / \mu \mathrm{g})$ as other osteogenic studies in 3D polyethylene glycol diacrylate hydrogels $(\sim 80 \mu \mathrm{g} / \mu \mathrm{g})$ and collagen gels $(\sim 200 \mu \mathrm{g} / \mu \mathrm{g}) .{ }^{58,59}$ The cell viability assays can be used to clarify this issue in the future. In addition, the high calcium contents per unit DNA and ALP activities in the high-density group may suggest that high seeding density improved the osteogenic differentiation of hUCMSCs. It was unexpected that the ALP activity at week 6 was slightly higher than at week 3 , since ALP is typically an earlier marker in osteogenic differentiation. However, there were no statistically significant differences between these two time points for the different seeding densities. Given that ALP activity is an early osteogenic indicator, ${ }^{60}$ we anticipated that ALP activities of hUCMSCs before week 3 would be remarkably higher than the ALP level we reported here, which illustrates a need for further investigation of ALP activities over a greater number of time points.

Cell-cell interaction influences cell behavior and ECM synthesis in both $2 \mathrm{D}^{61}$ and $3 \mathrm{D}^{23}$ environments. In this study, cell densities were determined by the initial seeding density and scaffold volume. Throughout the 6 weeks of culture, the low-density group formed a dense pellet with highly packed cells in a small amount of ECM, indicating a high cellularity might hinder ECM synthesis. In contrast, the medium- and high-density groups with a lower cellularity had more active bone-related ECM synthesis as evidenced by the higher HYP and calcium content per unit DNA and higher ALP activities. In the future, it will be useful to determine the effects of hUCMSC cell density on osteogenic differentiation by using a more slowly degrading scaffold that provides a fixed volume.
To better understand the osteoblastic differentiation of hUCMSCs at the mRNA level, gene expression was investigated during the first 3 weeks using the highest seeding density. Osteoblastic differentiation is a progressive process associated with over 20 genes. $^{62}$ In this study, RUNX2, OCN, $O P N$, and $C I$ were examined to evaluate the osteoblastic differentiation of hUCMSCs. The RUNX2 gene has been considered as a master gene required for osteoblastic differentiation at the early stage of differentiation. ${ }^{63-65}$ In RUNX2-deficient mice, the skeleton was cartilaginous and nonmineralized as no osteoblasts were present. ${ }^{66}$ The RUNX gene product binds to and regulates other genes such as $O C N, C I, O P N$, and bone sialoprotein, indicating that RUNX2 has a broader and sustained role in osteoblastic differentiation. ${ }^{63}$ Indeed, we noticed a rise of RUNX2 gene expression in the first week, which was maintained at a higher level than the control groups over the culture period. In contrast to the RUNX2 gene, the OCN and OPN genes are mainly expressed by mature osteoblasts at the late stage of osteoblastic differentiation. ${ }^{67}$ Expression of OCN and OPN genes has been shown to coincide with mineralization. ${ }^{67} \mathrm{We}$ did observe an increase of OCN during after the upregulation of the RUNX2 gene, while OPN gene expression decreased rapidly with time. Given that the OPN gene is not an osteogenic-specific gene and has been also identified in umbilical cord stroma itself, ${ }^{14}$ it is possible that OPN gene expression level after the rapid decrease from week 0 in this study still fell in a similar range to osteoblasts and other MSCs. This necessitates further comparative studies between UCMSCs and other cell types. In addition to the OCN and $O P N$ genes, expression of $C I$ gene was also shown to be important for osteoblast differentiation, matrix formation, ${ }^{68}$ and mineralization of osteoblasts. ${ }^{69} \mathrm{CI}$ gene expression of hUCMSCs did increase with time during the 3-week culture, which coincided with the increase of HYP and the increase of RUNX2 gene expression. Therefore, the rise of RUNX2, OCN, and $C I$ genes, combined with the increase of ALP activity and mineralization, indicates that hUCMSCs differentiated along an osteoblast-like lineage.

In summary, the osteogenic differentiation of hUCMSCs in a $3 \mathrm{D}$ biomaterial-based environment provides the foundation for future applications of this new cell source for bone tissue engineering. As we progress toward better osteogenic differentiation in the future, it will be crucial to not only examine gene expression, biosynthesis, and histology for osteogenic markers, but also evaluate the quality of mineralized tissue formation with methods such as transmission electron microscopy to determine whether actual bone-like tissue has been created. ${ }^{70}$ A higher seeding density in PGA scaffolds is a critically important factor to promote ECM synthesis and osteogenic differentiation. Given the clear advantages of hUCMSCs discussed earlier, and their capacity for osteogenic differentiation shown here, we conclude that hUCMSCs may indeed be a highly desirable cell source for bone tissue engineering, and that a higher seeding density is desirable (25 million cells/mL or higher) in 3D PGA scaffolds. Following this initial proof of concept with hUCMSCs in a $3 \mathrm{D}$ in vitro bone tissue engineering application, the optimization of osteogenic culture environment, a comparison between hUCMSCs and hBMSCs/fibroblasts in a 3D environment, and the use of a scaffold with a slower degradation 
rate should be investigated in the future, with an in-depth analysis of the mineralization quality.

\section{Acknowledgments}

We gratefully acknowledge support from the Arthritis Foundation, both from the national organization and from the Kansas Chapter. We would also like to thank Paul Glatt for proofreading the article.

\section{Disclosure Statement}

No competing financial interests exist.

\section{References}

1. Salgado, A.J., Coutinho, O.P., and Reis, R.L. Bone tissue engineering: state of the art and future trends. Macromol Biosci 4, 743, 2004.

2. Kretlow, J.D., and Mikos, A.G. Review: mineralization of synthetic polymer scaffolds for bone tissue engineering. Tissue Eng 13, 927, 2007.

3. Dawson, J.I., and Oreffo, R.O. Bridging the regeneration gap: stem cells, biomaterials and clinical translation in bone tissue engineering. Arch Biochem Biophys 473, 124, 2008.

4. Rose, F.R., and Oreffo, R.O. Bone tissue engineering: hope vs hype. Biochem Biophys Res Commun 292, 1, 2002.

5. Siddappa, R., Fernandes, H., Liu, J., van Blitterswijk, C., and de Boer, J. The response of human mesenchymal stem cells to osteogenic signals and its impact on bone tissue engineering. Curr Stem Cell Res Ther 2, 209, 2007.

6. Stenderup, K., Justesen, J., Clausen, C., and Kassem, M. Aging is associated with decreased maximal life span and accelerated senescence of bone marrow stromal cells. Bone 33, 919, 2003.

7. Mueller, S.M., and Glowacki, J. Age-related decline in the osteogenic potential of human bone marrow cells cultured in three-dimensional collagen sponges. J Cell Biochem 82, 583, 2001.

8. Lee, S.Y., Miwa, M., Sakai, Y., Kuroda, R., Matsumoto, T., Iwakura, T., Fujioka, H., Doita, M., and Kurosaka, M. In vitro multipotentiality and characterization of human unfractured traumatic hemarthrosis-derived progenitor cells: a potential cell source for tissue repair. I Cell Physiol 210, 561, 2007.

9. Troyer, D.L., and Weiss, M.L. Wharton's jelly-derived cells are a primitive stromal cell population. Stem Cells 26, 591, 2008.

10. Can, A., and Karahuseyinoglu, S. Concise review: human umbilical cord stroma with regard to the source of fetusderived stem cells. Stem Cells 25, 2886, 2007.

11. Seshareddy, K., Troyer, D., and Weiss, M.L. Method to isolate mesenchymal-like cells from Wharton's jelly of umbilical cord. Methods Cell Biol 86, 101, 2008.

12. Wang, L., Seshareddy, K., Weiss, M.L., and Detamore, M.S. Effect of initial seeding density on human umbilical cord mesenchymal stromal cells for fibrocartilage tissue engineering. Tissue Eng A 15, 1009, 2008.

13. Karahuseyinoglu, S., Cinar, O., Kilic, E., Kara, F., Akay, G.G., Demiralp, D.O., Tukun, A., Uckan, D., and Can, A. Biology of stem cells in human umbilical cord stroma: in situ and in vitro surveys. Stem Cells 25, 319, 2007.

14. Weiss, M.L., Medicetty, S., Bledsoe, A.R., Rachakatla, R.S., Choi, M., Merchav, S., Luo, Y., Rao, M.S., Velagaleti, G., and Troyer, D. Human umbilical cord matrix stem cells: pre- liminary characterization and effect of transplantation in a rodent model of Parkinson's disease. Stem Cells 24, 781,2006

15. Carlin, R., Davis, D., Weiss, M., Schultz, B., and Troyer, D. Expression of early transcription factors Oct4, Sox2 and Nanog by porcine umbilical cord (PUC) matrix cells. Reprod Biol Endocrinol 4, 8, 2006.

16. Wang, H.S., Hung, S.C., Peng, S.T., Huang, C.C., Wei, H.M., Guo, Y.J., Fu, Y. S., Lai, M.C., and Chen, C.C. Mesenchymal stem cells in the Wharton's jelly of the human umbilical cord. Stem Cells 22, 1330, 2004.

17. Wu, K.H., Zhou, B., Lu, S.H., Feng, B., Yang, S.G., Du, W.T., $\mathrm{Gu}$, D.S., Han, Z.C., and Liu, Y.L. In vitro and in vivo differentiation of human umbilical cord derived stem cells into endothelial cells. J Cell Biochem 100, 608, 2007.

18. Lu, L.L., Liu, Y.J., Yang, S.G., Zhao, Q.J., Wang, X., Gong, W., Han, Z.B., Xu, Z.S., Lu, Y.X., Liu, D., Chen, Z.Z., and Han, Z.C. Isolation and characterization of human umbilical cord mesenchymal stem cells with hematopoiesissupportive function and other potentials. Haematologica 91, 1017, 2006.

19. Honsawek, S., Dhitiseith, D., and Phupong, V. Effects of demineralized bone matrix on proliferation and osteogenic differentiation of mesenchymal stem cells from human umbilical cord. J Med Assoc Thai 89 Suppl 3, S189, 2006.

20. Schneider, R.K., Puellen, A., Kramann, R., Raupach, K., Bornemann, J., Knuechel, R., Perez-Bouza, A., and Neuss, S. The osteogenic differentiation of adult bone marrow and perinatal umbilical mesenchymal stem cells and matrix remodelling in three-dimensional collagen scaffolds. Biomaterials 31, 467, 2010.

21. Zhang, Z.Y., Teoh, S.H., Chong, M.S., Schantz, J.T., Fisk, N.M., Choolani, M.A., and Chan, J. Superior osteogenic capacity for bone tissue engineering of fetal compared with perinatal and adult mesenchymal stem cells. Stem Cells 27, 126, 2009.

22. Wang, L., Singh, M., Bonewald, L.F., and Detamore, M.S. Signalling strategies for osteogenic differentiation of human umbilical cord mesenchymal stromal cells for 3D bone tissue engineering. J Tissue Eng Regen Med 3, 398, 2009.

23. Bitar, M., Brown, R.A., Salih, V., Kidane, A.G., Knowles, J.C., and Nazhat, S.N. Effect of cell density on osteoblastic differentiation and matrix degradation of biomimetic dense collagen scaffolds. Biomacromolecules 9, 129, 2008.

24. Holy, C.E., Shoichet, M.S., and Davies, J.E. Engineering three-dimensional bone tissue in vitro using biodegradable scaffolds: investigating initial cell-seeding density and culture period. J Biomed Mater Res 51, 376, 2000.

25. Sumanasinghe, R.D., Osborne, J.A., and Loboa, E.G. Mesenchymal stem cell-seeded collagen matrices for bone repair: effects of cyclic tensile strain, cell density, and media conditions on matrix contraction in vitro. J Biomed Mater Res A 88, 778, 2009.

26. Edwards, C.A., and O'Brien, W.D. Modified assay for determination of hydroxyproline in a tissue hydrolyzate. Clin Chim Acta 104, 161, 1980.

27. Boyan, B.D., Schwartz, Z., Bonewald, L.F., and Swain, L.D. Localization of 1, 25-(OH) 2D3-responsive alkaline phosphatase in osteoblast-like cells (ROS 17/2.8, MG 63, and MC 3T3) and growth cartilage cells in culture. J Biol Chem 264, 11879, 1989.

28. ter Brugge, P.J., and Jansen, J.A. In vitro osteogenic differentiation of rat bone marrow cells subcultured with and without dexamethasone. Tissue Eng 8, 321, 2002. 
29. Livak, K.J., and Schmittgen, T.D. Analysis of relative gene expression data using real-time quantitative PCR and the 2(-Delta Delta C(T)) method. Methods 25, 402, 2001.

30. Bianco, P., Riminucci, M., Gronthos, S., and Robey, P.G. Bone marrow stromal stem cells: nature, biology, and potential applications. Stem Cells 19, 180, 2001.

31. Zuk, P.A., Zhu, M., Ashjian, P., De Ugarte, D.A., Huang, J.I., Mizuno, H., Alfonso, Z.C., Fraser, J.K., Benhaim, P., and Hedrick, M.H. Human adipose tissue is a source of multipotent stem cells. Mol Biol Cell 13, 4279, 2002.

32. Childs, R., Chernoff, A., Contentin, N., Bahceci, E., Schrump, D., Leitman, S., Read, E.J., Tisdale, J., Dunbar, C., and Linehan, W.M. Regression of metastatic renal-cell carcinoma after nonmyeloablative allogeneic peripheral-blood stem-cell transplantation. N Engl J Med 343, 750, 2000.

33. Broxmeyer, H.E., Douglas, G.W., Hangoc, G., Cooper, S., Bard, J., English, D., Arny, M., Thomas, L., and Boyse, E.A. Human umbilical cord blood as a potential source of transplantable hematopoietic stem/progenitor cells. Proc Natl Acad Sci U S A 86, 3828, 1989.

34. Jones, E.A., English, A., Henshaw, K., Kinsey, S.E., Markham, A.F., Emery, P., and McGonagle, D. Enumeration and phenotypic characterization of synovial fluid multipotential mesenchymal progenitor cells in inflammatory and degenerative arthritis. Arthritis Rheum 50, 817, 2004.

35. Huelsken, J., Vogel, R., Erdmann, B., Cotsarelis, G., and Birchmeier, W. Catenin controls hair follicle morphogenesis and stem cell differentiation in the Skin. Cell 105, 533, 2001.

36. Seale, P., Asakura, A., and Rudnicki, M.A. The potential of muscle stem cells. Dev Cell 1, 333, 2001.

37. Gronthos, S., Mankani, M., Brahim, J., Robey, P.G., and Shi, S. Postnatal human dental pulp stem cells (DPSCs) in vitro and in vivo. Proc Natl Acad Sci U S A 97, 13625, 2000.

38. Bailey, M.M., Wang, L., Bode, C.J., Mitchell, K.E., and Detamore, M.S. A comparison of human umbilical cord matrix stem cells and temporomandibular joint condylar chondrocytes for tissue engineering temporomandibular joint condylar cartilage. Tissue Eng 13, 2003, 2007.

39. Eblenkamp, M., Aigner, J., Hintermair, J., Potthoff, S., Hopfner, U., Jacobs, V., Niemeyer, M., and Wintermantel, E. [Umbilical cord stromal cells (UCSC). Cells featuring osteogenic differentiation potential]. Orthopade 33, 1338, 2004.

40. Mitchell, K.E., Weiss, M.L., Mitchell, B.M., Martin, P., Davis, D., Morales, L., Helwig, B., Beerenstrauch, M., Abou-Easa, K., Hildreth, T., Troyer, D., and Medicetty, S. Matrix cells from Wharton's jelly form neurons and glia. Stem Cells 21, 50, 2003.

41. Sarugaser, R., Lickorish, D., Baksh, D., Hosseini, M.M., and Davies, J.E. Human umbilical cord perivascular (HUCPV) cells: a source of mesenchymal progenitors. Stem Cells 23, 220, 2005.

42. Baksh, D., Yao, R., and Tuan, R.S. Comparison of proliferative and multilineage differentiation potential of human mesenchymal stem cells derived from umbilical cord and bone marrow. Stem Cells 25, 1384, 2007.

43. Fu, Y.S., Shih, Y.T., Cheng, Y.C., and Min, M.Y. Transformation of human umbilical mesenchymal cells into neurons in vitro. J Biomed Sci 11, 652, 2004.

44. Yang, L.Y., Zheng, J.K., Wang, C.Y., and Xu, M.D. [Stromal cells from human Wharton's jelly differentiate into neural cells]. Sichuan Da Xue Xue Bao Yi Xue Ban 36, 13, 2005.

45. Fu, Y.S., Cheng, Y.C., Lin, M.Y., Cheng, H., Chu, P.M., Chou, S.C., Shih, Y.H., Ko, M.H., and Sung, M.S. Conversion of human umbilical cord mesenchymal stem cells in Whar- ton's jelly to dopaminergic neurons in vitro: potential therapeutic application for Parkinsonism. Stem Cells 24, 115, 2006.

46. Martin, J.A., Hamilton, B.E., Sutton, P.D., Ventura, S.J., Menacker, F., Kirmeyer, S., and Munson, M.L. Births: final data for 2005. Natl Vital Stat Rep 56, 1, 2007.

47. Weiss, M.L., Mitchell, K.E., Hix, J.E., Medicetty, S., ElZarkouny, S.Z., Grieger, D., and Troyer, D.L. Transplantation of porcine umbilical cord matrix cells into the rat brain. Exp Neurol 182, 288, 2003.

48. Cho, P.S., Messina, D.J., Hirsh, E.L., Chi, N., Goldman, S.N., Lo, D.P., Harris, I.R., Popma, S.H., Sachs, D.H., and Huang, C.A. Immunogenicity of umbilical cord tissue derived cells. Blood 111, 430, 2008.

49. Medicetty, S., Bledsoe, A.R., Fahrenholtz, C.B., Troyer, D., and Weiss, M.L. Transplantation of pig stem cells into rat brain: proliferation during the first 8 weeks. Exp Neurol 190, 32, 2004.

50. Kadner, A., Zund, G., Maurus, C., Breymann, C., Yakarisik, S., Kadner, G., Turina, M., and Hoerstrup, S.P. Human umbilical cord cells for cardiovascular tissue engineering: a comparative study. Eur J Cardiothorac Surg 25, 635, 2004.

51. Schmidt, D., and Hoerstrup, S.P. Tissue engineered heart valves based on human cells. Swiss Med Wkly 137 Suppl 155, 80S, 2007.

52. Schmidt, D., Mol, A., Odermatt, B., Neuenschwander, S., Breymann, C., Gossi, M., Genoni, M., Zund, G., and Hoerstrup, S.P. Engineering of biologically active living heart valve leaflets using human umbilical cord-derived progenitor cells. Tissue Eng 12, 3223, 2006.

53. Breymann, C., Schmidt, D., and Hoerstrup, S.P. Umbilical cord cells as a source of cardiovascular tissue engineering. Stem Cell Rev 2, 87, 2006.

54. Schmidt, D., and Hoerstrup, S.P. Tissue engineered heart valves based on human cells. Swiss Med Wkly 136, 618, 2006.

55. Schmidt, D., Asmis, L.M., Odermatt, B., Kelm, J., Breymann, C., Gossi, M., Genoni, M., Zund, G., and Hoerstrup, S.P. Engineered living blood vessels: functional endothelia generated from human umbilical cord-derived progenitors. Ann Thorac Surg 82, 1465, 2006.

56. Wang, L., and Detamore, M.S. Insulin-like growth factor-I improves chondrogenesis of predifferentiated human umbilical cord mesenchymal stromal cells. I Orthop Res 27, 1109, 2009.

57. Wang, L., Tran, I., Seshareddy, K., Weiss, M.L., and Detamore, M.S. A comparison of human bone marrow-derived mesenchymal stem cells and human umbilical cord-derived mesenchymal stromal cells for cartilage tissue engineering. Tissue Eng A 15, 2259, 2008.

58. Meinel, L., Karageorgiou, V., Fajardo, R., Snyder, B., ShindePatil, V., Zichner, L., Kaplan, D., Langer, R., and VunjakNovakovic, G. Bone tissue engineering using human mesenchymal stem cells: effects of scaffold material and medium flow. Ann Biomed Eng 32, 112, 2004.

59. Yang, F., Williams, C.G., Wang, D.A., Lee, H., Manson, P.N., and Elisseeff, J. The effect of incorporating RGD adhesive peptide in polyethylene glycol diacrylate hydrogel on osteogenesis of bone marrow stromal cells. Biomaterials 26, 5991, 2005.

60. Jaiswal, N., Haynesworth, S.E., Caplan, A.I., and Bruder, S.P. Osteogenic differentiation of purified, culture-expanded human mesenchymal stem cells in vitro. J Cell Biochem 64, 295, 1997.

61. Neuhuber, B., Swanger, S.A., Howard, L., Mackay, A., and Fischer, I. Effects of plating density and culture time 
on bone marrow stromal cell characteristics. Exp Hematol 36, 1176, 2008.

62. Huang, W., Yang, S., Shao, J., and Li, Y.P. Signaling and transcriptional regulation in osteoblast commitment and differentiation. Front Biosci 12, 3068, 2007.

63. Ducy, P., Zhang, R., Geoffroy, V., Ridall, A.L., and Karsenty, G. Osf2/Cbfa1: a transcriptional activator of osteoblast differentiation. Cell 89, 747, 1997.

64. Schroeder, T.M., Jensen, E.D., and Westendorf, J.J. Runx2: a master organizer of gene transcription in developing and maturing osteoblasts. Birth Defects Res C Embryo Today 75, 213, 2005.

65. Tou, L., Quibria, N., and Alexander, J.M. Transcriptional regulation of the human Runx2/Cbfa1 gene promoter by bone morphogenetic protein-7. Mol Cell Endocrinol 205, 121, 2003.

66. Otto, F., Thornell, A.P., Crompton, T., Denzel, A., Gilmour, K.C., Rosewell, I.R., Stamp, G.W., Beddington, R.S., Mundlos, S., Olsen, B.R., Selby, P.B., and Owen, M.J. Cbfa1, a candidate gene for cleidocranial dysplasia syndrome, is essential for osteoblast differentiation and bone development. Cell 89, 765, 1997.

67. Lian, J.B., Stein, G.S., Stein, J.L., and van Wijnen, A.J. Osteocalcin gene promoter: unlocking the secrets for regulation of osteoblast growth and differentiation. J Cell Biochem Suppl 30, 62, 1998.

68. Nakashima, K., Zhou, X., Kunkel, G., Zhang, Z., Deng, J.M., Behringer, R.R., and de Crombrugghe, B. The novel zinc finger-containing transcription factor osterix is required for osteoblast differentiation and bone formation. Cell 108, 17, 2002.

69. Uzawa, K., Grzesik, W.J., Nishiura, T., Kuznetsov, S.A., Robey, P.G., Brenner, D.A., and Yamauchi, M. Differential expression of human lysyl hydroxylase genes, lysine hydroxylation, and cross-linking of type I collagen during osteoblastic differentiation in vitro. J Bone Miner Res 14, 1272, 1999.

70. Bonewald, L., Harris, S., Rosser, J., Dallas, M., Dallas, S., Camacho, N., Boyan, B., and Boskey, A. von Kossa staining alone is not sufficient to confirm that mineralization in vitro represents bone formation. Calcif Tissue Int 72, 537, 2003.

Address correspondence to: Michael S. Detamore, Ph.D. Department of Chemical and Petroleum Engineering University of Kansas 4132 Learned Hall, $1530 \mathrm{~W} 15^{\text {th }}$ St. Lawrence, KS 66045

E-mail: detamore@ku.edu

Received: October 26, 2009

Accepted: January 13, 2010

Online Publication Date: February 22, 2010 
This article has been cited by:

1. Limin Wang, Lindsey Ott, Kiran Seshareddy, Mark L Weiss, Michael S Detamore. 2011. Musculoskeletal tissue engineering with human umbilical cord mesenchymal stromal cells. Regenerative Medicine 6:1, 95-109. [CrossRef] 